\title{
E-MODUL SISTEM PERSAMAAN LINIER SEBAGAI BAHAN AJAR MEMAHAMI MATERI ALJABAR MATRIK
}

\author{
E-MODUL OF LINEAR SYSTEM EQUATION AS TEACHING \\ MATERIALS TO UNDERSTAND MATRIX ALGEBRA LESSON
}

\author{
Soffi Widyanesti Priwantoroa, Rima Aksen Cahdriyana ${ }^{b}$ \\ a Program Studi Pendidikan Matematika FKIP UAD, soffiwidyanesti@ pmat.uad.ac.id \\ ${ }^{\mathrm{b}}$ Program Studi Pendidikan Matematika FKIP UAD, rima.cahdriyana@ pmat.uad.ac.id
}

\begin{abstract}
ABSTRAK
Kemajuan teknologi dan informasi mempengaruhi ranah pendidikan yang berakibat mengubah sumber belajar dari tradisional yang diakses secara offline menjadi online. Salah satu perubahan yang terjadi adalah modul yang berupa cetak, saat ini marak modul yang bersifat elektronik. Inti dari pembelajaran aljabar matriks adalah operasi baris elementer, Eliminasi gaussjordan, dan solusi sistem persamaan linier. Materi-materi tersebut digunkaan sebagai prasyarat dasar untuk aljabar linier dan pemrograman linier, sehingga mahasiswa diharapkan memahami materi tersebut. Modul yang bersifat elektronik atau e-modul yang dikembangkan menggunakan flipbook kvisoft yang dapat disisipi dengan video, gambar dan audio yang memungkinkan mahasiswa belajar diluar kelas. Metode yang digunakan dalam pengembangan ini adalah ADDIE (analysis, Desain, Developm Implementation, Evaluation). Haisl dari penelitian ini adalah dikembangkannya e-modul matriks dengan kriteria layak yaitu $76,25 \%$ dari ahli media dan $78,57 \%$ dari ahli materi. Sednagkan untuk respon mahasiswa diperoleh kriteria praktis pada kelas kecil dengan prosentase sebesar $65,20 \%$ dan kelas besar sebesar 77,03\%.
\end{abstract}

Kata Kunci : modul elektronik, matriks, flipbook

\begin{abstract}
Progress in technology and information field affect in education field ti change the kearning source form traditional that only that only accessed offline to digital that can be accessed online. One of changing from printed module to electronic module. One of the core of matrix algebra lesson is elementary row operation, Gauss Jordan Elimination, and kinds of solution in linier equation system. Those material who used as basic prerequisite for linear algebra dan linear programming, so its force the student to understand the material. Electronic module (e-module) bassed on kvisoft flipbook maker can be inesrted with audio ad video who possibility to learn outside the classroom. The method used ini this research is research and development using ADDIE (Analysis, Design, Develop, Implement, Evaluate). Development of e-module matrix algebra have viable criteria that is $76,25 \%$ from media experts and 78,57\% from material experts. Meanwhile through the questionaire response obtained practical criteria with small class test $65,20 \%$ and large class test $77,03 \%$.
\end{abstract}

Keywords : electronic module, matrix, flipbook 


\section{Pendahuluan}

Pentingnya peranan matematika terlihat dalam porsinya mata pelajaran tersebut disetiap tingkatan pendidikan, karena dengan mempelajari matematika peserta didik dapat berfikir secara logis, kritis, sistematis, rasional dan cermat (Ana S, 2018). Hal ini memberikan tantangan bagi pendidik untuk meningkatkan proses pembelajaran matematika dari waktu ke waktu seiring dnegan perubahan zaman. Proses pembelajaran dapat berhasil selain tergantung pada metode juga bergantung pada perangkat pembelajaran yang digunakan (Tjiptiany, 2016). Sehingga penggunaan bahan ajar atau buku pada proses pembelajaran merupakan salah satu hal yang penting, karena bahan ajar disusun sejalan dengan kemampuan kognitif peserta didik yang mengikuti proses pembelajaran. Salah satu alternatif bahan ajar yang dapat digunakan adalah modul, karena modul dapat disusun secara menarik dan sistematis (Isna, 2017).

Perkembangan teknologi dan informasi saat ini telah merambah termasuk pada bidang pendidikan (Priwantoro, 2019). Hal ini merupakan pembaharuan yang juga perlu diperhatikan dalam mempengaruhi proses pembelajaran dikelas. Hal ini sejalan dengan Ganefri (2017) penggunaan teknologi informasi dan komunikasi dapat mendukung dan meningkatkan kemampuan peserta didik dari segi kognitif, afektif dan kemampuan sosial bahkan untuk yang kemampuan tinggi. Sehingga penggunaan teknologi informasi menjadi suatau kebutuhan yang penting (Darmaji, 2019).

Kemajuan di bidang teknologi informasi dibidang pendidikan telah merubah sumber belajar dan perangkat pembelajaran dari proses pembelajaran berubah dari konvensional yang bisa diakses offline berubah menjadi bentuk digital yang dpat diakses secara online (Divayana, 2019). Salah satu sumber belajar yang berubah adalah yang semula printed module saat ini berubah dalam bentuk e-modul atau electronic module. E-modul dapat dimodifikasi sedemikian rupa sehingga dapat mudah diakses, menarik dan interaktif. Salah satu software yang dapat digunakan untuk mengembangkan e-modul yang menarik adalah kvisoft flipbook maker. Kvisoft Flipbook maker adalah media yang bisa merubah document word ke dalam PDF dan berbentuk flipbook yang dapat ditampilkan menjadi modul digital yang bervariasi, inovatif dan efektif (Fahmi, 2019).

Media Pembelajaran berupa modul dapat ditransformasikan penyajiannya kedalam bentuk elektronik sehingga diberi istilah modul elektronik atau modul virtual. Modul elektronik adalah sebuah 
bentuk penyajian bahan belajar mandiri yang disusun secara sistematis ke dalam unit pembelajaran terkecil untuk mencapai tujuan pembelajaran tertentu yang disajikan dalam bentuk elektronik yang didalamnya terdapat animasi, audio, navigasi yang membuat pengguna lebih interaktif dengan software. Modul elektronik yang bersifat interaktif ini pada proses pembelajarannya akan melibatkan tampilan audio visual, sound, movie dan yang lainnya serta software tersebut pemakaiannya mudah dipahami sehingga dapat dijadikan media pembelajaran yang baik (Gunawan, 2010).

Aljabar Matrik adalah salah satu mata kuliah yang harus ditempuh oleh mahasiswa di program studi pendidikan matematika FKIP UAD. Pada mata kuliah ini dosen pengampu menggunakan buku referensi dari schaum dan buku Erlangga karangan Howard Anton selain itu belum ada dosen yang menyediakan emodul berbasis software tertentu. Salah satu materi inti dari perkuliahan aljabar matriks adalah pemahaman mengenai Operasi Baris Elementer atau yang lebih dikenal dengan OBE, Eliminasi Gauss dan Gauss Jordan, Penentuan solusi dari suatu Sistem Persamaan Linier. Materi ini inilah yang akan digunakan sebagai dasar atau prasyarat untuk mengambil mata kuliah Aljabar Linier dan Program Linier, sehingga mahasiswa wajib memahami materi agar pelaksanaan dua mata kuliah selanjutnya lebih dapat dipahami. Pada materi tersebut diperlukan aplikasi untuk menjelaskan tatacara atau prosedur dan aturan OBE, dan kegiatan perkuliahan dikelas tidak bisa mencukupi jika tidak ada pembelajaran yang dilakukan mahasiswa diluar kelas. Salah satu aplikasi software untuk e-modul adalah kvisoft flipbook maker, aplikasi ini mendukung sebagi e-modul yang membantu proses pembelajaran karena tidak terpaku pada tulisan saja namun juga animasi gerak, video dan audio yang menjadikannya e-modul yang interaktif (Wibowo, 2018). Dari kelebihan kvisoft flipbook maker ini, yaitu dapat disisipi animasi berupa audio dan video yang memungkinkan dipelajari oleh mahasiswa diluar kelas. Hal ini memotivasi penulis untuk mengembangkan e-modul yang berbasis software kvisoft flipbook maker agar mendorong mahasiswa untuk dapat memahami materi yang menjadi prasyarat bagi perkuliahan selanjutnya secara mandiri.

\section{Metode Penelitian}

Metode yang digunakan pada penelitian ini adalah metode penelitian dan pengembangan (research and development). Model yang digunakan adalah ADDIE (Analysis, Design, Develop, Implement, Evaluate). Model pengembangan ADDIE merupakan model desain pembelajaran yang 
berlandasan pada pendekatan sistem yang efektif dan efisien serta prosesnya yang bersifat interaktif yakni hasil evaluasi setiap fase dapat membawa pengembangan pembelajaran ke fase selanjutnya. Hasil akhir dari suatu fase merupakan produk awal bagi fase berikutnya. Pada gambar 1. Berikut diberikan tahapan model pengembangan ADDIE.

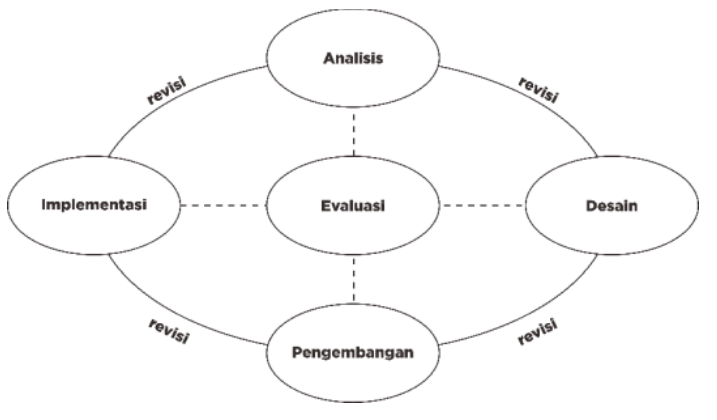

Gambar 1. Tahapan model pengembangan ADDIE

\section{Tahap Analisis}

Tahap ini dilakukan dengan mendefinisikan apa yang akan dipelajari oleh peserta didik. Maka untuk mengetahui atau menentukan apa yang harus dipelajari, diperlukan beberapa kegiatan diantaranya analisis kebutuhan, analisis situasi dan analisis teknologi. Hal ini dilakukan untuk menentukan sasaran dari pengguna media, apa saja yang dipelajari, pengetahuan-pengetahuan sebagai persyaratan yang harus dimiliki, durasi waktu efektif yang diperlukan dalam penggunaan suatu e-modul dalam proses pembelajaran.

a. Analisis kebutuhan
Analisis kebutuhan dilakukan untuk dasar mengetahui perlu atau tidaknya penggunaan e-modul ini dalam kegiatan pembelajaran.

b. Analisis situasi

Analisis situasi dilakukan untuk mengetahui kondisi dari perkuliahan yang digunakan sebagai objek penelitian. Dengan cara observasi untuk mengetahui proses pembelajaran yang dilaksanakan di program studi pendidikan matematika

c. Analisis teknologi

Analisis teknologi dilakukan dengan cara mengetahui software yang sesuai dengan kemampuan peneliti dan kebutuhan pengembangan emodul.

\section{Tahap Desain}

Setelah dilakukan analisis, selanjutnya masuk pada tahap desain. Pada tahap ini yang dilakukan adalah membuat rancangan produk e-modul. Diperlukan adanya klarifikasi program pembelajaran yang telah direncanakan agar tujuan pembelajaran yang diharapkan dapat tercapai. Berdasarkan hasil analisis, pada tahap desain dilakukan :

a. Perancangan desain produk

Desain produk yang peneliti buat berupa storyboard yang berisi tentang alur cerita dalam e-modul dan flowchart yang berisi alur e- 
modul secara ringkas. Penentuan materi dan pengumpulan buku-buku untuk Pembuatan soal dan jawaban.

b. Perangkat

Pemilihan software dalam penelitian ini disesuaikan dengan hasil analisis kebutuhan, analisis situasi dan analisis teknologi yang telah peneliti lakukan. Pengumpulan informasi tersebut digunakan untuk pembuatan e-modul.

\section{Tahap Pengembangan}

Menurut Tegeh (2014) kegiatan pengembangan merupakan kegiatan menerjemahkan spesifikasi desain ke dalam bentuk fisik, sehingga pada tahapan ini dihasilkan produk pengembangan. Pada tahap ini dilakukan

a. Pembuatan produk

Produk dibuat dengan menggunakan kvisoft. Semua bahan baik desain, materi, efek suara, dan video digabungkan menggunakan aplikasi tersebut.

b. Validasi dari ahli

Produk yang telah dibuat divalidasi oleh ahli media dan ahli materi

c. Revisi

Setelah melalui proses validasi, dilakukan revisi pada produk berdasarkan komentar, saran dan masukan dari ahli media supaya lebih menarik, ahli materi untuk membetulkan kesalahan materi.

\section{Tahap Implementasi}

Pada tahap ini dilakukan uji coba produk pada pmahasiswa prodi pendidikan matematika.. Pribadi (2009) menyatakan bahwa tujuan utama dari tahap implementasi antara lain:

a. Membimbing peserta didik untuk mencapai tujuan pembelajaran atau kompetensi,

b. Menjamin terjadinya pemecahan masalah/solusi untuk mengatasi kesenjangan hasil belajar yang dihadapi oleh peserta didik, dan

c. Memastikan bahwa pada akhir program pembelajaran peserta didik perlu memiliki kompetensi, pengetahuan, keterampilan, dan sikap yang diperlukan.

Pada tahap ini dilakukan pembagian angket untuk mengetahui pendapat/respon peserta didik mengenai produk yang telah dibuat. Bila diperlukan maka dilakukan revisi tahap II sesuai masukan dari peserta didik. Namun, dalam revisi ini dilakukan pertimbangan berdasarkan masukan dan saran validator 
sebelumnya, agar tidak bertentangan dengan perbaikan-perbaikan sebelumnya.

\section{Tahap Evaluasi}

Pada tahap ini, dilakukan evaluasi pada emodul. Evaluasi dilakukan pada penelitian berdasarkan hasil angket evaluasi yang diberikan kepada ahli media, ahli materi, dan peseta didik atau peserta didik yang mengikuti implementasi. Tujuan tahap evaluasi terhadap program pembelajaran menurut Tegeh (2014) antara lain:

a. Mengetahui sikap peserta didik terhadap kegiatan pembelajaran secara keseluruhan,

b. Mengetahui peningkatan kompetensi dalam diri peserta didik yang merupakan dampak dari keikutsertaan dalam program pembelajaran, dan

c. Mengetahui keuntungan yang dirasakan oleh sekolah akibat adanya peningkatan kompetensi peserta didik setelah mengikuti program pembelajaran

Desain Uji coba Produk meliputi dua tahapan, uji yang dilakukan oleh penguji validasi materi dan media yang dilakukan oleh dosen. Setelah media pembelajaran dinyatakan baik, uji coba tahap terakhir dilakukan yaitu dengan melibatkan mahasiswa semester 2 pendidikan matematika yaitu sebagai dosen ahli materi Dr. Burhanudin Arif N., M.Sc. dan dosen ahli media rima
Aksen Cahdriyana, M.Pd. Subjek ujicoba pada peneltiian ini ada tiga yaitu Dosen ahli materi, Dosen ahli media dan mahasiswa pendidikan matematika. Ahli materi dalam penelitian ini adalah dosen pendidikan matematika Universitas Ahmad Dahlan. Materi dalam media yang telah dibuat dinilai oleh ahli materi. Penilaian yang dilakukan tidak sebatas pada segi materi saja, akan tetapi instrumen yang telah dibuat oleh peneliti. Ahli materi memberikan penilaian serta masukan guna perbaikan pada media pembelajaran. Ahli media dalam penelitian ini adalah dosen pendidikan matematika Universitas Ahmad Dahlan. Penilaian yang diberikan oleh ahli media berupa penyajian media serta aspek lain melalui instrumen yang telah dibuat oleh peneliti. Subjek Uji coba bahan ajar emodul adalah Mahasiswa Program Studi Pendidikan Matematika semester dua. Dalam uji coba e-modul, peneliti menjelaskan materi aljabar matriks dengan menggunakan e-modul kepada mahasiswa, setelah itu mahasiswa diminta untuk mengisi angket. mahasiswa juga diminta memberi masukan dan saran untuk perbaikan emodul.

Instrumen yang digunakan dalam penelitian ini adalah :

a. Angket untuk ahli materi 
Angket dibuat dan dikembangkan berdasarkan kriteria penilaian media pembelajaran dan desain media pembelajaran. Angket ini digunakan untuk mengetahui kesesuaian media pembelajaran aspek pendidikan. Sebelum digunakan, angket terlebih dahulu di uji validitasnya..

a. Angket untuk ahli media

Angket dibuat dan dikembangkan berdasarkan kriteria penilaian media pembelajaran dan kriteria rekayasa perangkat lunak. Angket ini digunakan untuk mengetahui kesesuaian media pembelajaran aspek tampilan program. Sebelum digunakan, angket terlebih dahulu di uji validitasnya.

b. Angket untuk mahasiswa

Angket dibuat dan dikembangkan berdasarkan kriteria penilaian media pembelajaran dan kriteria komunikasi visual. Angket ini digunakan untuk mengetahui kesesuaian media pembelajaran aspek kualitas teknis. Sebelum digunakan, angket terlebih dahulu di uji validitasnya. Angket ini akan digunakan kepada 10 mahasiswa Prodi Pendidikan Matematika Semester 2 FKIP Universitas Ahmad Dahlan.

Metode Angket digunakan untuk mengukur indikator e-modul ini menggunakan nilai skor yaitu 4,3,2,1 dari modifikasi skala Likert, dimana alternatif responnya adalah SS (Sangat Setuju), S (Setuju), KS (Kurang Setuju), TS(Tidak Setuju). Skala Likert digunakan untuk mengukur sikap, pendapat dan persepsi seseorang atau kelompok tentang media yang kita hasilkan. Dalam skala Likert terdapat dua jenis pernyataan yaitu pernyataan negatif dan pernyataan postif. Berikut diberikan tabel pernyataan positif dan negatif.

Tabel 1. Pernyataan positif dan negatif pada skala likert modifikasi

\begin{tabular}{llll}
\hline Pernyataan Positif & \multicolumn{3}{c}{ Pernyataan Negatif } \\
Sangat Setuju & $(\mathrm{SS})=4$ & Sangat Setuju & $(\mathrm{SS})=1$ \\
Setuju & $(\mathrm{S})=3$ & Setuju & $(\mathrm{S})=2$ \\
Kurang Setuju & $(\mathrm{KS})=2$ & Kurang Setuju & $(\mathrm{KS})=3$ \\
Tidak Setuju & $(\mathrm{TS})=1$ & Tidak Setuju & $(\mathrm{TS})=4$ \\
\hline
\end{tabular}


Teknik analisis data yang digunakan dalam penelitian ini adalah

a. Proses analisis deskriptif

Langkah pada proses ini meliputi menghimpun data yaitu melakukan pemisahan antara data yang penting dengan data yang tidak penting, menampilkan data yaitu melakukan penyusunan data dengan baik dan benar sedemikan sehingga seluruh data yang diperoleh dari hasil penilaian dan masukan ahli ditampilkan secara deskriptif. Kemudian reduksi data yaitu menyederhanakan data yang telah diperoleh. Langkah terakhir adalaha verifikasi dan interpretasi data yaitu menarik kesimpulan berdasarkan data hasil penilaian para ahli.

b. Proses analisis angket

Proses ini terbagi dua yaitu analisis data validasi produk dan analisis keptraktisan produk. Analisis data validasi produk didapatkan dari data hasil validasi dari ahli materi dan ahli media terhadap produk emodul berupa data kuantitaif dan data kualitatif. Data kualitatif berupa kritik dan saran yang dikemukakan ahli media dan ahli materi. Sedangkan data kuantitatif yang diperoleh dari ahli media dan ahli materi dianalisis secara deskriptif Berikut diberikan tabel 2 mengenai pemberian skor pada angket untuk ahli media dan ahli materi.

Tabel 2. Aturan pemberian skor

\begin{tabular}{ll}
\hline Karakter & Skor \\
Sangat baik & 4 \\
Baik & 3 \\
Cukup & 2 \\
Kurang & 1 \\
\hline Dari data yang dikumpulkan kemudian
\end{tabular}

akan dihitung rata-ratanya dengan rumus:

$$
K=\frac{F}{N \times I \times R}
$$

Keterangan :

$\mathrm{K}$ : Persentase kelayakan

F : Jumlah keseluruhan jawaban responden

$\mathrm{N}$ : Skor Tertinggi dalam angket

I : Jumlah pertanyaan dalam angket

$\mathrm{R}$ : Jumlah responden (sumber : Palelupu dan Cholik, 2014:4)

Aspek validitas dalam penelitian pengembangan meliputi validitas isi dan validitas konstruk (Rochmad,2012). Suatu modul dikatakan valid saat modul dikatakan layak dengan revisi dan layak tanpa revisi oleh validator baik media maupun materi. Untuk menilai kevalidan media digunakan instrumen oenilaian kevalidan yang divalidasi oleh validator. Validator akan memberikan saran dan masukan terkait kevalidan modul yang sedang dikembangkan. Setelah perhitungan persentase kelayakan yang diinterpretasikan menurut tabel berikut. 
Table 3. Persentase kelayakan

\begin{tabular}{ll}
\hline Persentase & Kriteria \\
$0 \% \leq \boldsymbol{K} \leq 20 \%$ & $\begin{array}{l}\text { Sangat Tidak } \\
\text { Baik }\end{array}$ \\
$20 \%<\boldsymbol{K} \leq 40 \%$ & Kurang Baik \\
$40 \%<\boldsymbol{K} \leq 60 \%$ & Cukup \\
$60 \%<\boldsymbol{K} \leq 80 \%$ & Baik \\
$80 \%<\boldsymbol{K} \leq 100 \%$ & Sangat Baik \\
\hline
\end{tabular}

Bahan ajar layak digunakan apabila mendapatkan persentase lebih dari $60 \%$ dengan kriteria baik maupun sangat baik.

Sedangkan analisis kepraktisan produk diperoleh dari saat ahli/praktisi mengatakan produk yang dikembangkan dapat diterapkan di lapangan (Rochmad, 2012). Kepraktisan dalam pengembangan produk ini adalah dilihat dari angket respon yang diberikan kepada mahasiswa. Angket respon digunakan untuk mengetahui respon mahasiswa terhadap produk yang dikembangan mengenai kecocokan dan kemudahan penggunaan produk. Produk dikatkan praktis ketika mahasiswa memperoleh respon yang baik terhadap produk yang dikembangkan. Angket respon kepada mahasiswa tentunya divalidasi oleh dosen ahli dan diinterpretasikan pada tabel berikut.
Tabel 4. Kriteria Kepraktisan

\begin{tabular}{ll}
\hline Persentase & Kriteria \\
$0 \% \leq K \leq 20 \%$ & $\begin{array}{l}\text { Sangat Tidak } \\
\text { Praktis }\end{array}$ \\
$20 \%<\boldsymbol{K} \leq 40 \%$ & Kurang Praktis \\
$40 \%<\boldsymbol{K} \leq 60 \%$ & Cukup \\
$60 \%<\boldsymbol{K} \leq 80 \%$ & Praktis \\
$80 \%<\boldsymbol{K} \leq 100 \%$ & Sangat Praktis \\
\hline $\begin{array}{l}\text { Produk layak digunakan jika mendapatan } \\
\text { prosentase lebih dari } 60 \% \text { dengan kriteria }\end{array}$ \\
praktis maupun sangat praktis.
\end{tabular}

\section{Hasil dan Pembahasan}

Hasil penelitian yang akan dikemukakan pada bab ini adalah dari proses analisis hingga evaluasi produk bahan ajar emodul. Pada tahap analisis, melalui wawancara diperoleh informasi dari mahasiswa bahwa untuk memahami materi operasi baris elementer pada mata kuliah aljabar matrik membutuhkan banyak waktu untuk memahami di luar kelas. Sementara saat perkuliahan tidak ada modul yang memuat video yang bisa diputar ulang untuk membantu ketika belajar kembali diluar kelas. Berdasarkan hasil angket yang disebarkan kepada mahasiswa diperoleh hasil seperti gambar 2. dibawah ini. 


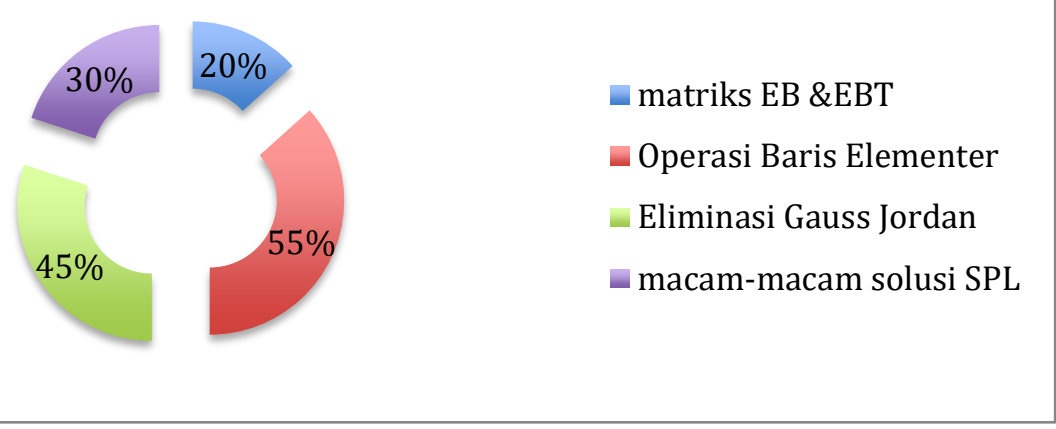

Gambar 2. Grafik kesulitan Mahasiswa dalam Aljabar Matriks

Dari gambar 2, terlihat bahwa 55\% mahasiswa mengalami kesulitan dalam memahami operasi baris elementer dan $45 \%$ mengenai eliminasi gauss jordan. Seperti kita ketahui seorang mahsiswa yang tidak dapat memahami operasi baris elementer maka mahasiswa tersebutakan mengalami kesulitan dalam menggunakan eliminasi gauss jordan. Dari analisis tersebut maka dibutuhkan media yang memuat video penjelasan mengenai operasi baris elementer. Kemudian dilakukan studi literatur untuk menganalisa materi matriks eselon baris dan eselon baris terreduksi, operasi baris elementer, eliminasi gauss jordan, dan jenis-jenis solusi Sistem persamaan linier yang akan dibuat dalam media menggunakan software kvisoft dan video scribe. Untuk bahan ajar e-modul yang akan digunakan menggunakan share link yang akan bertaut di google drive. Langkah selanjutnya adalah mengumpulkan referensi buku yang mendukung untuk mengembangkan bahan ajar diantaranya buku milikhoward anton, schaums pengantar aljabar matriks. Selain buku cetak juga digunakan buku digital atau e-book yang bisa dicari melalui google.

Pada tahap desain yang dilakukan adalaha menganalisa isi kurikulum, yaitu memilah materi ang sesuai untuk disampaikan pada bahan ajar e-modul. Materi tersebut dipilah dari sumber buku yang dijadikan oleh peneliti. Kemudian penyusunan story board untuk e-modul aljabar matriks yang berbasis kvisoft dan video scribe. Hal ini dilakukan untuk mempermudah pembuatan bahan ajar e0modul dan sebagai acuan proses pembuatan bvahan ajar e-modul. Peneliti juga memilih beberapa contoh soal yang akan digunakan dalam pembuatan video penjelasan mengenai matriks eselon baris dan eselon baris tereduksi, operasi baris elementer, eliminasi gauss jordan, solusi sistem persamaan linier. Contoh soal yang dipilih adalah contoh soal yang mudah dipahami oleh mahasiswa.

Pada tahap pengembangan ada beberapa software yang digunakan yaitu kvisoft flipbook maker, video scribe, microsoft word, dan corel draw X4. 
Selain itu juga dilakukan pembuatan apersepsi untuk meingingatkan mahasiswa bahwa materi mengenai alajabar matriks ini akan digunakan sebagai mata kuliah dasar pada aljabar linier dan program linier, sehingga pemahaaman materi tentang aljabar matriks ini penting untuk kelanjutjan perkuliahan di semester depan. Kemudia pembuatan tampilan capaian pembelaajran yang harus dikuasai oleh mahasiswa dan pembuatan simulasi penjelasan mengenai matriks eselon baris dan baris tereduksi, operasi baris elementer, eliminasi gauss jordan, solusisolusi sistem persamaan linier.

Pada tampilan awal yang muncul saat penggunan membuka bahan ajar emodul adalah munculnya cover halaman e-modul aljabar matriks, sebagaimana terlihat pada gambar 3 berikut.

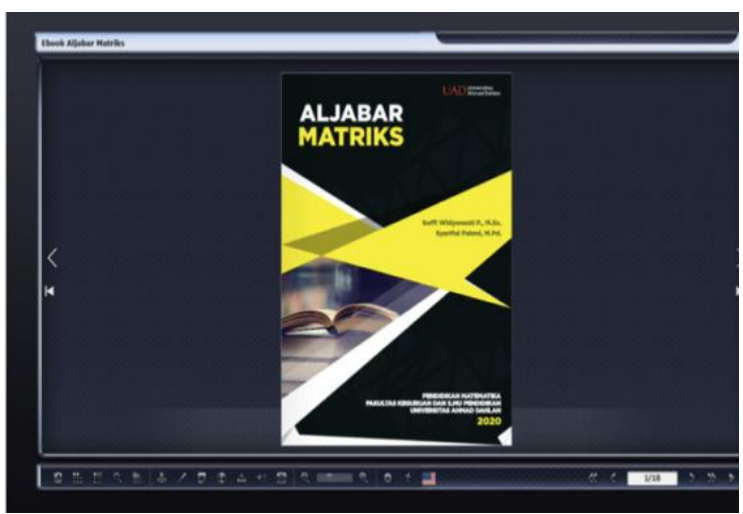

Gambar 3. Tampilan awal emodul

Halaman seanjutnya pada e-modul aljabar matriks adalah halaman prakata dan halaman sampul yang berisi tentang penulis dan editor serta validator e- modul. Berikut gambar yang menunjukkan halaman sampul dan prakata pada e-modul aljaabar mtariks.

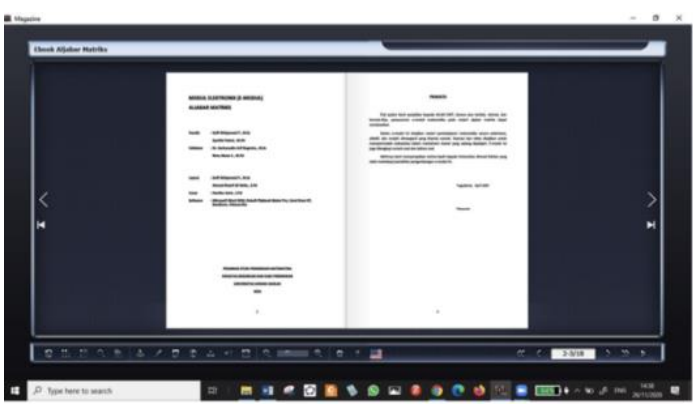

Gambar 4. Halaman sampul dan prakata

Halaman selanjutnya mengenai capaian kompetensi yang wajib dikuasai oleh mahasiswa untuk materi matriks eselon baris dan eselon baris tereduksi.

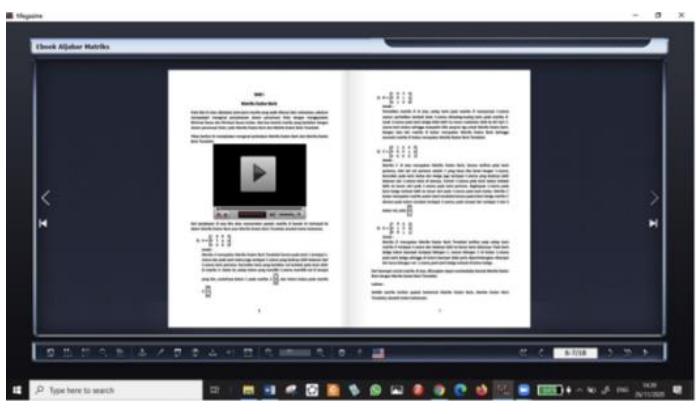

Gambar 6. Capaian kompetensi untuk materi matrisk eselon baris dan eselon baris teeduksi

Pada gambar 6. terlihat ada video mengenai perbedaan matriks eselon baris, eselon baris tereduksi dan bukan keduanya.

Pada setiap bab e-modul terdapat video penjelasan untuk mempermudah pemahaman mahasiswa mengenai bab yang bersangkutan. E-modul ini terdaapt 4 bab yang didalamnya termuat video pembelajaran, seperti contohnpada bab 3 
mengenai eliminasi gauss jordan beriku ini.

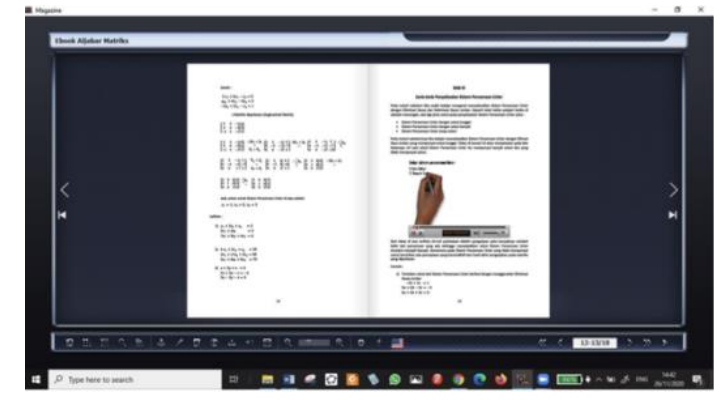

Gambar 7. Video penjelasan materi bab Eliminiasi Gauss Jordan

Pada gambar 7., terdapat video scribe penjelasan mengenai langkah penyelesaian suatu sistem persamaan linier dengan menggunakan eliminasi gauss jordan dengan solusi tunggal.

Setiap bab pada e-modul aljabar matriks terdapat soal latihan yang dapat dikerjakan mahasiswa ketika mempelajari materi pada bab yang bersangkutan. Terdapat contoh soal yang dikerjakan dengan langkah yang detail kemudian diikuti dengan beberapa soal latihan yang bisa dikerjakan oleh mahasiswa. Contoh soal dan soal latihan akan termuat di settiap bab pada e-mpdul alajabar matriks. Dan contoh soal yang dikerjakan dengan langkah yang detail agar dpat dengan mudah dipahami ooleh mahasiswa. Hal ini dilakukan untuk mendukung video yang sudah termuat di setiap bab pada e-modul aljabar matriks.

Pada halaman akhir e-mopdul terdapat daftar pustaka sebagai referensi pembuatan e-mpdul aljabar matriks dengan bantuan kvisoft flipbook maker dan video scribe.

Selain itu juga adanya profil dari pemyusun e-mpdul agar saat e-modul ini bisa terpublikasi dengan luas, pengguna bisa menghubungi penyusun dengan harapan dapat memberikan kritik dan saran yang membangun.

Tahap selanjutnya adalah tahap implementasi yaitu menerapkan e-modul aljabar matriks kepada mahasiswa pendidikan matematika semester dua FKIP universitas Ahmad Dahlan. Setelah dilakukan perbaikan terhadap masukan dari ahli amteri dan ahli media, peneltii kemudia melakukan ujicoba kelas kecil pada mahasiswa dan dilakukan secara daring. Peneliti memberikan link google drive kepada mahasiswa untuk selanjtunya dapat didownload dan dipelajari, kemudian pada kelas kecil tersebut dibagikan angket untuk melihat kepraktisan dari e-mpdul yang sudah dikembangkan.

Setelah dilakukan uji coba kelas kecil dan belum ada masukan dari mahasiswa terhadap e-mpdul, peneliti melakukan uji coba kelas besar yaitu mahassiwa Pendidikan Matematika Kelas B semester dua FKIP Universitas Ahmad Dahlan. Proses uji coba kelas besar juga dilakukan secara daring karena adanya pandemi covid -19 yang belum mereda. Teknis uji coba kelas besar sama dengan saat uji coba kelas kecil yaitu 
membagikan link pada google drive untuk kemudian mahasiwa mendownload dan mengisi angket respon mahasiswa.

Tahap terakhir pada penelitian pengembangan ini adalah tahap evaluasi yaitu tahap analisis validitas produk dilakukan oleh ahli materi dan ahli media dengan validatior yang relevan dibidang aljabar untuk dosen ahli materi dan validator dibidang teknologi media untuk memvalidasi secara estetika media. Angket untuk ahli materi dan ahli media dihitung dengan menggunakan rumus yang tertera pada bab metode dan diperoleh hasil sebagai berikut.

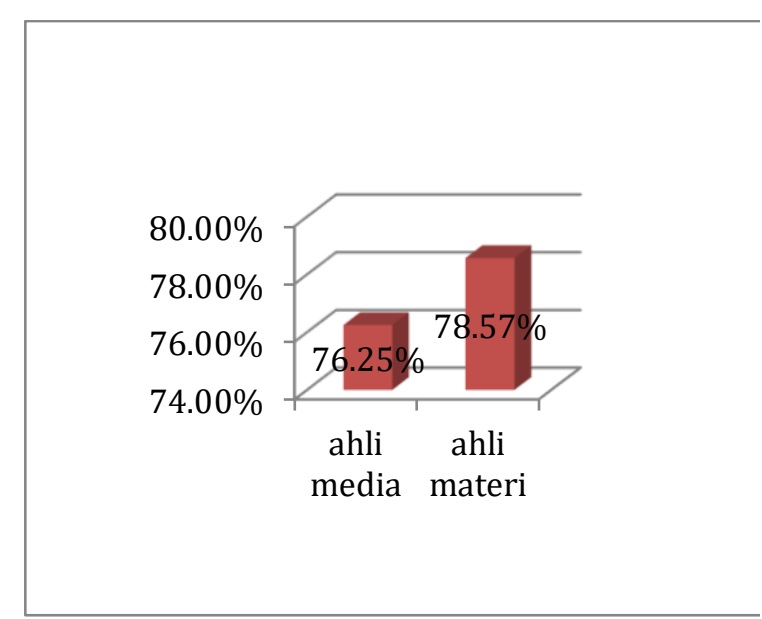

Gambar 8. Hasil Validasi Ahli

Terlihat dari gambar 2. Pada ahli materi menunjukkan hasil $78,57 \%$ yang berkriteria baik untuk kelayakan bahan ajar. Sementara untuk ahli media menunjukkan hasil 76,25\% yang berarti media mempunyai kelayakan dengan kriteria baik.

Berdasarkan kriteria pada ahli media dan ahli materi produk bahan ajar termasuk pada kriteria baik,untuk menilai kepraktisan bahan ajar e-modul diperlukan aspek uji coba lapangan. Pada uji coba lapangan baik kelas kecil maupun kelas besar, mahasiswa diberi angket respon, berikut diberikan data hasil respon angket baik kelas kecil maupun kelas besar

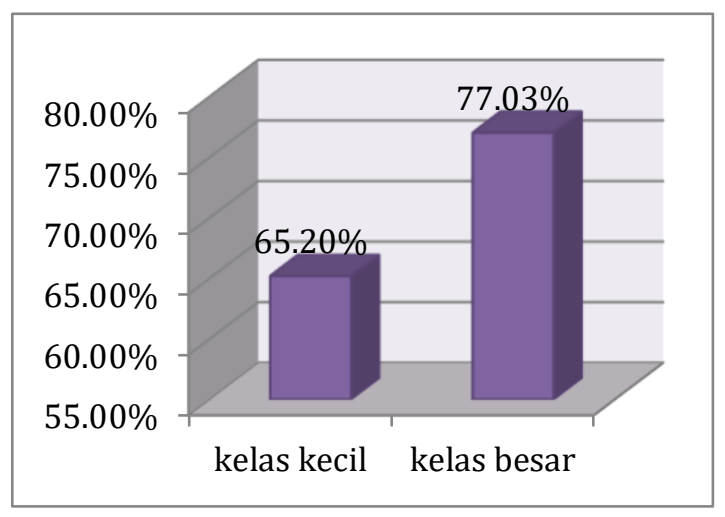

Gambar 9. Hasil Uji Coba Kelas

Bedasarkan diagram diatas, dapat disimpulkan perhitungan respon mahsiswa baik pada kelas kecil dan kelas besar berada pada kriteria praktis. Dari analisis validitas dan kepraktisan e-modul aljabar matrik maka dapat disimpulkan bahwa e-modul aljabar matriks layak dan praktis sebagi bahan ajar untuk membantu memahamkan mahasiswa mengenai materi matriks eselon baris dan eselon baris tereduksi, operasi baris elemnter, eliminasi gaussjordan dan jenis solusi sistem persamaan linier.

\section{Kesimpulan}

Penelitian ini telah berhasil mengemabangakn e-mdoul aljabar 
matriks dengan materi matriks eselon baris dan eselon baris tereduksi, operasi baris elementer, eliminasi gauss jordan, dan jenis solusi sistem persaman linier bagi mahasiswa pendidikan matematika semester dua dengan menggunakan model ADDIE. Pengembangan e-mdpul ini telah melakukan setiap tahapan pada model ADDIE dan berdasarkan penilaian oleh ahli media dan ahli materi serta respon mahasiswa baik kelas kecil maupun kelas besar diperoleh e-modul aljabar matriks layak dan praktis digunakan.

\section{Pustaka}

Darmaji, D., Astalini, A., Kurniawan, D., Parasdila, H., Irdianti, I., Susbiyanto, S., .. \& Ikhlas, M. (2019). E-Module based problem solving in basic physics practicum for science process skills. International Journal of Online and Biomedical engineering, 15(15), 4-17

Divayana, D. G. H., Santiyadnya, N., Ratnaya, I. G., Sudirtha, I. G., \& Darmayasa, I. P. (2019). Digital book for assessment and evaluation courses based on Kvisoft-kelase asynchronous pattern. Telkomnika, 17(1), 328-336

Fahmi, S., Priwantoro, S. W., Cahdriyana, R. A., Hendroanto, A., Rohmah, S. N., \& Nisa, L. C. (2019, March). Interactive Learning Media Using Kvisoft Flipbook Maker for Mathematics Learning. In Journal of
Physics: Conference Series (Vol. 1188, No. 1, p. 012075). IOP Publishing.

Ganefri, H. H., Kusumaningrum, I., \& Mardin, A.(2017a). Needs Analysis of Entrepreneurship Pedagogy of Technology and Vocational Education with Production Base Learning Approach in Higher Education. International Journal on Advanced Science, Engineering and Information Technology, 7(5), 17011707.

Gunawan, Dedi. (2010). Modul pembelajaran Interaktif eleketronik dasar Untuk Program Keahlian Teknik Audio vIdeo SMK Muhammadiyah 1 Sukoharjo Menggunakan Macromedia Falsh 8. Jurnal Komuniti. Vol 2. 2010

Pribadi, B. A. (2009). Model desain sistem pembelajaran. Jakarta: Dian Rakyat, 35.

Priwantoro, S. W., Fahmi, S., \& Astuti, D. (2019, January). Pengembangan EModul Berbasis Kvisoft Flipbook Maker Dipadukan Dengan Geogebra Sebagai Alternatif Media Pembelajaran Mata Kuliah Program Linier. In Seminar Nasional Pendidikan Matematika Ahmad Dahlan (Vol. 6).

Rafianti, I. (2017, May). Pengembangan Modul Pembelajaran Matematika dengan Pendekatan Saintifik pada Materi Matriks Kelas XI SMA. 
In Prosiding Seminar Nasional

Pendidikan FKIP (Vol. 1, No. 2).

Rochmad, R. (2012). Desain Model Pengembangan Perangkat

Pembelajaran Matematika. Kreano, Jurnal Matematika KreatifInovatif, 3(1), 59-72.

Setiani, A., Kartiwi, A. P., \& Wulandari, H. (2017). Pengembangan Bahan Ajar Kompilasi Berupa Modul Pada Mata Kuliah Aljabar Matriks di Universitas Muhammadiyah Sukabumi. Supremum Journal of Education Mathematics, 2(1), 26-31.

Tegeh, I. M., Jampel, I. N., \& Pudjawan, K. (2014). Model penelitian pengembangan. Yogyakarta: Graha Ilmu.

Tjiptiany, E. N., As'ari, A. R., \& Muksar, M. (2016). Pengembangan modul pembelajaran matematika dengan pendekatan inkuiri untuk membantu siswa SMA kelas $\mathrm{X}$ dalam memahami materi peluang. Jurnal Pendidikan: Teori, Penelitian, dan Pengembangan, 1(10), 1938-1942.

Wibowo, E., \& Pratiwi, D. D. (2018). Pengembangan bahan ajar menggunakan aplikasi kvisoft flipbook maker materi himpunan. Desimal: Jurnal Matematika, 1(2), 147 
